\title{
Hani Nationality Culture under the Modern Perspective
}

\author{
Xin Wang \\ School of Music \\ Honghe University \\ Mengzi, Yunnan, China 661199
}

\begin{abstract}
During the process of entering into the modernity process, China society is feeling the "modernity experience", which deep influence and spread into every level of China society, change and reform the features of the traditional culture. As one of the component elements in multi-peoples family of China, it is inevitable that the Hani nationality culture falls in to the history whirlpool of the modernity experience, to survey the situation of Hani nationality culture via the modernity sight can help us to deep understand the modernity situation of Hani nationality culture.
\end{abstract}

Keywords - modernity; modernity experience; Hani culture

\section{INTRODUCTION}

The "modernity experience" of Chinese society began in the middle of the 19th century, it is a kind of mandatory input product from the western culture by the way of "gunboats" and also is the result that China was passively integrated in the process of "globalization". The Hani nationality society, as one of the component element of China society, conforms to the general trend of the history development during the contacting process of "modernity experience". From the realistic level, many parts of the traditional culture of Hani nationality have been lost, but it only is the very common situation when the two kinds of cultures come across with each other, which can not deny the active modernity influence to the development of Hani nationality society.

\section{MODERNITY PERMEATION AND TRANSITION OF HANI NATIONALITY}

As a minority influenced by the Han nationality culture, the permeation of Hani nationality is more obvious, and it is mainly presented in the social change of Hani society in the 20 th century. There are profound and complex conflict between the modernity permeate and the Hani traditional society, which mainly displays that they fall into the "logagnosia" mode caused by modern culture, that is to say, they lose their logical thinking method, emotional express pattern and value standard. For the current Hani people, they are not only lack of the guarantee system to compete the modern culture, but also do not set up the way of narration on the ideological level. To stand the tradition of Hani people is not simple ethnic emotion problems, but refers to the historical and cultural situation of the special people in current society, whose deep culture system should be attracted enough attention from us. We should recognize that "When two or more societies contact with each other directly and continuously, the culture transition will be done at the same time. In all almost conditions, the 'net flow' of the culture always goes toward the weak from the strong" [1].

Hani people live in the broad area in southwest border of China for a long time, their life is rarely disturbed from external factors, which can keep their primitiveness, but also cut off the possibilities that the external culture influences the local nation. But the development of the whole society is often not changed according to an individual consciousness and national preferences, and it must face the changing history of the whole society. Thus, the "modernity" from the western society has gradually permeated into the life of Hani people in the public spread way, and is obviously displayed on the permeation and influence to the established way of their life. As Alex Inkeles says in the Modernization: "using a radio is likely to be the beginning of his really participate in the world", "in our view, a modern people should always keep in touch with the mass media, such as newspaper, film, radio, and if it is possible, also including TV", "the modern people more trust the new mass communication, while the less modern people rely on traditional sources" ${ }^{\text {[2]. }}$.

The culture of the Hani society and the western modernity civilization are derived from their respective cultural soil, they respectively provide plenty of intellectual support and spiritual nourishment to their own people. Therefore, we can not think that the civilization breeds from a higher level of material productivity is better than the other civilization. We even can say that the Hani traditional culture has absolute power of expression in the spirit world for the Hani people, which is more than the effectiveness of emotional express brought by current civilization. Many of the researchers on ethnology, aesthetics often inspect the minority living around us by the looking down attitude. The negative impact brought by this research model has attracted more attention from academia, when we inspect the impact brought by modernity to the Hanni nationality, we can not merely comb its history, but also need to deep research what kind of influence has been brought to the Hani people, and what is the strategy we should use to deal with it?

The traditional culture of Hani people will not gradually lose its words and expression ability via the permeation process of modern culture, but they should adopt cautious and 
suitable strategy to adjust the relation between the traditional culture and the modern social life. In fundamental sense, when people of Hani nation accept the life style, spiritual world and emotion memory brought by the modern civilization, they also accept the group memory of Chinese nation, which means that they choose to accept the multi-ethnic national community. To the people of Hani nationality in the traditional society, they continuously develop in the odd communication wit other many nationalities. Though they are influenced by the culture of Han at a certain degree, it can not bring essential reform to the society of Hani nation. This situation has been gradually changed after the founding of new China, and be developed to current state, which has been given detail discussion in this article. In this process, the younger generation of Hani nationality has basically reached the medium culture, and goes into the new social structure step by step. When they learn the Chinese characters, they also accept the Han nationality as the main body of the community of multi-ethnic country, and begin to learn and follow the thinking method that different from Hani nationality.

The fast development of the modern big industry and business society changes the people's thinking value and active mode via the slow and fast methods. Whether we want to accept it or not, they industrial culture permeation and business activity factors have come into our life. With the fast development of information technology, the traditional spread way has been gradually replaced by fast and simple spread method, which promotes the disappearance of the traditional society and construction process fro building society. Compare with Han nationality and areas populated with Han people, the development of minority and its living area are slow. In the late 1980 s and the early 1990 s, the crisis to the traditional culture of minority has appeared: the ethnic songs sung by Mopi of the Hani nationality has begin to disappear, there are a few of young people can sing them; the ethnic medicine begin to lose their market, exquisite national architecture and its technology begin to decline; the traditional customers begin to be given up and so on. There is no change till now, and even much worse. Though the government has made some countermeasures, and carries out a series of protection strategy to protect its culture, the effectiveness is very small. When the modern culture permeate every corner of the society, the convenient transportation and the open information can connect the backwoodsman minority with the modern metropolis, when the backwoodsman find the convenience brought by the modern culture, the tradition life style will lose their attraction to these people, and can not stop the younger generation to say goodbye to the tradition. Not only the Hani people, a lot of young adults in the former relatively backward minority region all choose a new way to make a living, they are forgetting their national tradition.

\section{The CHALlenge FACING BY THE DEVELOPMENT OF HANI NATIONS UNDER MODERNIZATION BACKGROUND}

\section{A. Limit Factors to the Development of Hani Culture}

At the beginning when the modern consumption idea and the commodity economy began to develop in Hani area, these negative factors will be displayed via the public's some concept and behavior, many of them will lose psychological endurance, and do not know what to do. To some extent, it blocks the development of commodity economy and modernization construction, it is inevitable that there are conflicts between the traditions and the modernity. These restrictive factors are mainly the following several aspects.

1) Geographical environment: A nation or state, if it lived in closed geographical environment in a long-term, rarely communicate with the outside world, it will be not exposed to the outside world, thus it is easy to get into the situation of the conservative. The Hani nationality, living in Ailao Mountains, with high mountains and deep valley, is hidden in the remote, the traffic is not developed. This almost closed geographical environment, on the one hand, block the spread of outside information, and also the immigrants can't move in great quantities, it is difficult that the advanced culture and the information are spread into the mountains; On the other hand, this kind of environment is conducive to form a self-contained production and lifestyle, Hani nation depends on the natural environment to make terrace and form the agricultural civilization .Don't need advanced production tools and techniques, also do not need to spend too much energy, the most primitive extensive farming can meet the needs of the survival. Relatively closed space gives birth to the unique way of life, and creates the unique cultural psychological structure of Hani people. Hani people easily fall into conservative lax, blindly optimistic, fear and exclusive outside psychological state so it is lack of the enterprise struggle, competition and creation nature. Facts show that a nation can have vitality, prosperity and development only when it communicate, learn, compete and study together with other nations.

The geographical environment of Hani nation is occlusion and complicated, people's communication activities are greatly restricted. Hani people rarely contact with the outside world, the information is not developed, the communication is mostly limited between family and clan, village and village, and then form the self closed state. Hard living conditions, the backward mode of production and honest folkway make Hani populated areas well retain the remaining traces of the traditional barter in a long time, and the commodity economy didn't get development.

2) Ideology: Hani is located in the mountains with rich natural resources, however, most of the regional economic development of the Hani nationality is very slow. The development of modernization is to promote the development of commodity economy, it needs people to emancipate the mind, and accept new things. Hani self-sufficient natural economy is enough for Hani people's life, so the Hani people engage in single production activities for a long time, commodity economy basis and commodity economy consciousness are very weak. Besides, the Hani nation exist balanced psychology, although the balanced psychology can coordinate the relationship from person to person, family to family and village to village, which sustain the harmony and stability within the Hani nation for one thousand years, the 
balanced psychology also "kill the brave of Hani people, who dare not to try the unknown world but always confined to the known one which hindered their progress and development" [3]. These old ideas hidden deep in the Hani people's psychology, and hindered its development of commodity economy.

Another remarkable characteristic is its strong supernatural concepts. Because of low level productivity, backward economic development, Hani people have too much uncertainty on its own and are lack of confidence, so they hope to use the power of the ghosts and gods to help themselves. In Hani regions, ghosts and gods beliefs are very serious. When Hani people get sick, they seldom go to a hospital, because they think that the disease is the result of the ghosts and gods work instead of physical problems. Even after the other major accidents, Hani people always pin their hopes on ghosts and gods, hope that through sacrifice or other ways, offering of food to eliminate the evil problem solving, to solve their own problems. This backward, foolish ideas and behavior did not remove their disaster, sometimes the problem become more serious, and even lead to death. Religion becomes the dominant thought source of Hani people to deal with real problems, ritual activities is one of the solutions chosen by them. These means do not to raise the Hani people's production and living level, but block the development of the Hani science-education-culture-health career. By extension, some Hani people's daily life is very hard, but all kinds of ritual activities and weddings have become as the "pretext" for squandering wealth, which will burn off the limited wealth in a short time. They pour the accumulated wealth gotten by the perennial labor into the activities related to the tradition activities, which will cost much more than the daily life. The formation of this consumption idea is not in conformity with the basic requirements of the primitive accumulation of capital, severely restricts the development of the Hani social commodity economy factors.

3) Current education state: This modern education of Hanni nation is backward, and talent training can not keep up with the situation development needs. Long-term closed environment, and ancient concept- "Agriculture is more important than business" make Hani culture system look down upon the elements of the commodity economy, and which is displayed on the choosing the way of life between the young and the old man. Backward economy restricts the development of the Hani region culture, which is embodied in the relatively backward education supporting the cultural development. Basic education quality directly affects the development of the Hani nationality education and the cultivation of talents. Although the basic education degree is improved, the drop out of school situation of Hani teenagers is still very serious. On the other hand, there are only a few highly educated people, but it is difficult for them to get important mission, which is a common phenomenon in real life .Therefore, the countermeasures should be taken to reform, change the backward ethnic education, especially the state of low teaching quality. These factors are restricting the development of commodity economy and modernization of the Hani nationality, and bring bad influence to the development of social productivity to Hani region.

\section{B. "Convergence" and Vanishing Problems of Hani Culture}

The modernity has brought great changes to the traditional society of Hani nation and vastly improved the life, but it also has brought great challenges to the traditional culture. It is not difficult for us to understand the mentioned changes to educational system and ethnic clothes of Hani society, be carefully hidden under all kinds of excuses, we can see the compromise adopted by the Hani people to solve its survival and developing problems. Into to create more material wealth to exchange its self-development, the Hani people need to adjust itself according to the development of outside society. They need to introduce the modern education system for the next generation to receive advanced education to bring them out of the poverty and lag behind real situation; they also need to introduce more simple and convenient clothing in order to improve the efficiency of production. But inevitably, in this process, they also lose a lot of cultural tradition belongs to this nationality.

With the impact and penetration of the heterogeneous culture, the appearance of changing consciousness and opening consciousness, the aesthetic consciousness of the Hani nationality has obviously taken place in recent years, they prefer the novel and highlight things. Unlike the before situation, the rapid development of society and the plenty of new things make people open their eyes, their ability to accept new things is greatly enhanced. As the clothing of Han nation becomes wide variety with various style and colors, it attract the minorities that like decoration and bright colors.

The social popular clothing for all seasons has corresponded to the aesthetic psychology that pursuit the novel of Hani nation. Now the young generation of the Hani nationality began to discard the traditional simple draw, color dim national costumes, but liked a variety of clothing style. Hani guy started to wear t-shirts, girls don't wear trousers with broad edge but wear skirts, the important clothing for Hani cadres has become as suit. The daily life of Hani nation is coming close to the popular new things step by step. Hani ethnic costumes, whether women's clothing or men's clothing, still keep some traditional factors which is displayed through the dress in the daily life and some important festival, serious sacrificial activities, but also be penetrated into the some modern clothing content. In the modern Hani society, in daily life, only the old people keep on wearing traditional costumes, and for the younger generation, they like to choose more concise and clear, convenient modern clothing.

As Liangzhi Zhu talked at the Chinese Aesthetic Theory "the influence and impact to the aesthetic consciousness brought by the foreign culture not only make the aesthetic consciousness more universal, and also promote the development of the aesthetic consciousness. Assimilation of foreign culture and attract, the existing aesthetic consciousness has its own adaptability. When a nation's own culture including aesthetic consciousness loses its vitality, to the impact of foreign culture, the culture and aesthetic consciousness is vulnerable" [4]. Under the strong influence from Chinese and foreign cultures, the tradition of Hani 
nations is gradually lost. When the younger generation is eager to go out of the village and enter into the cities, their pursuit to the modern civilization and their desire to their own national culture has formed the intense conflict. The scholar at Yunnan frontier has exclaimed: "the traditional culture of ethnic minorities in southwest China is quickly losing, more worryingly that the fastest disappearing place of the traditional culture is not the regions that closely contact with the urban culture and has high economic level, but the minority parts that are originally blocked but heavily influenced by the foreign cultures in recent years."

At the "Long street Banquet" of Hani nationality, there is no longer has the traditional dishes of Hanni nationality; the " mushroom house" of Hani nationality has also vanished, some of them become as the quadrangles with three rooms and blue tiles, some of them has become as the modern building. Motorcycles, electric cars, cars also entered the Hani people's life. Pursuit novel has become as a trend, on the one hand, it can promote innovation and social progress, but on the other hand, it also leads to a negative result. The behind of pursuing the foreign culture of Hani nationality is the blind worship. After accept the foreign things, they will unconsciously overstate the advantages of foreign culture during the aesthetic process. They cannot see the advantages of traditional culture, which lead to lose the interest in traditional culture, and in the end the ethnic culture will be lost. School rarely carry out the relevant national culture courses, children rarely accept this aspect of education, Hani young people is not familiar with the history of the nation, and also have a strong resistant to the traditional way of life. The Hani traditional culture is becoming no features or collapse. These are the problems being faced by the Hani nationality in the process of modernization.

\section{CONCLUSION}

"If a nation lose its culture, in fact it equals to lose itself" (6). The traditional culture of Hani nationality is the spirit community that gradually accumulated in the long historical development process and precipitate in the deep heart of Hani people. There are many specific expression styles, which construct the unique cultural attributes of the Hani nationality. When Hani lose its nation's cultural characteristics, it no longer has the characteristics of this nation, and no longer be a people with complete sense. From the traditional society to the modern society, in this process, the traditional culture of Hani nation has experienced a painful experience that is gradually marginalized, it is more painful that the young generation of Hani nationality ignores and even negates the traditional culture. This makes the status of the traditional culture of Hani nationality in jeopardy, it is harder for us to feel the Hani ethnic characteristics from the younger generation. They go out of the mountains lived generations by generations to the city, they give up the "terrace" ways of making a living, which is the correct choice of Hani nationality to adapt the new times. But they are faced with the spiritual world of anxiety: on the one hand, they couldn't really enter into the modern metropolis, the life style, the pace of life and relationships are unprecedented; On the other hand, they also gradually lost their native cultural characteristics, and become as the "edge person" to their traditional culture. Therefore, how to keep the ethnic characteristics of Hani nationality during the process of modernization is worthy of our thinking? More fundamental problem is what factors cause the offset and marginalization of Hani ethnic characteristics? The latter is the foundation for us to solve the former, and we cannot direct the Hani nationality to keep its cultural features during the process of modernity only till we clarify the nature of the problem.

\section{REFERENCES}

[1] [U.S]Robert.F. Murphy Book. Culture Social Anthropology. Translated by Zhuojun Wang. Beijing: Commercial Press, in 1991, Page256Page 257.

[2] [U.S]Alex Ingels Book. Human modernization-psychology ideology attitude behavior. Translated by Jun Lu. Sichuan People's Press, In 1985, Page 140

[3] Wenjing Lu: Discussion on Hani Balanced Psychology Theory. Mainly edited by Zixian Li, Qibo Li. The 1st International Academic Conference on Hani Culture Kunming: Yunnan Nationalities Press, in 1996, page 111.

[4] Liangzhi Zhu: Chinese Aesthetic Theory. Beijing: Peking University Press, in 2005, Page 145

[5] Tie Fang: About then Salvage, Protection and Development of Minority Ethnic Tradtinal Culture in Western Part, edited by Yunnan Ethnic School. Economy, Globalization and National culture diversified development. Beijing: Social and Science Literature Press, in 2003, page 67.

[6] Qiong He: Western National Culture Research. Beijing: Ethnic Press, in 2005, Page 340 